\title{
Axon initial segment potassium channel density in cortical neurons
}

Wen Zhang, Boqiang Fan, Ping Zheng, Yuguo Yu*

From 24th Annual Computational Neuroscience Meeting: CNS*2015

Prague, Czech Republic. 18-23 July 2015

There is a growing interest in estimating actual density ranges of $\mathrm{Na}+$ channels in the very thin axon, especially in the action potential (AP) initiation zone, i.e., the axon initial segment (AIS, 20-50 microns away from the cell body). Both immunostaining studies and patch-clamp recordings indicated a relatively high density of $\mathrm{Na}+$ channels in AIS of either pyramidal regular-spiking (RS) cells
[1] or fast-spiking (FS) GABAergic interneurons [2,3]. Here, we investigated potassium channel densities in AISs of both RS and FS cells in same recording conditions.

Our axonal recordings directly revealed that there is a very lower potassium density $\mathrm{gK}=185.8 \pm 19 \mathrm{pS} / \mu \mathrm{m} 2$ $\mathrm{N}=16)$ for the RS AIS while a higher gK $(495.7 \pm 108$ $\mathrm{pS} / \mu \mathrm{m} 2, \mathrm{~N}=11$ ) for FS AIS, see Figure 1A. For both the
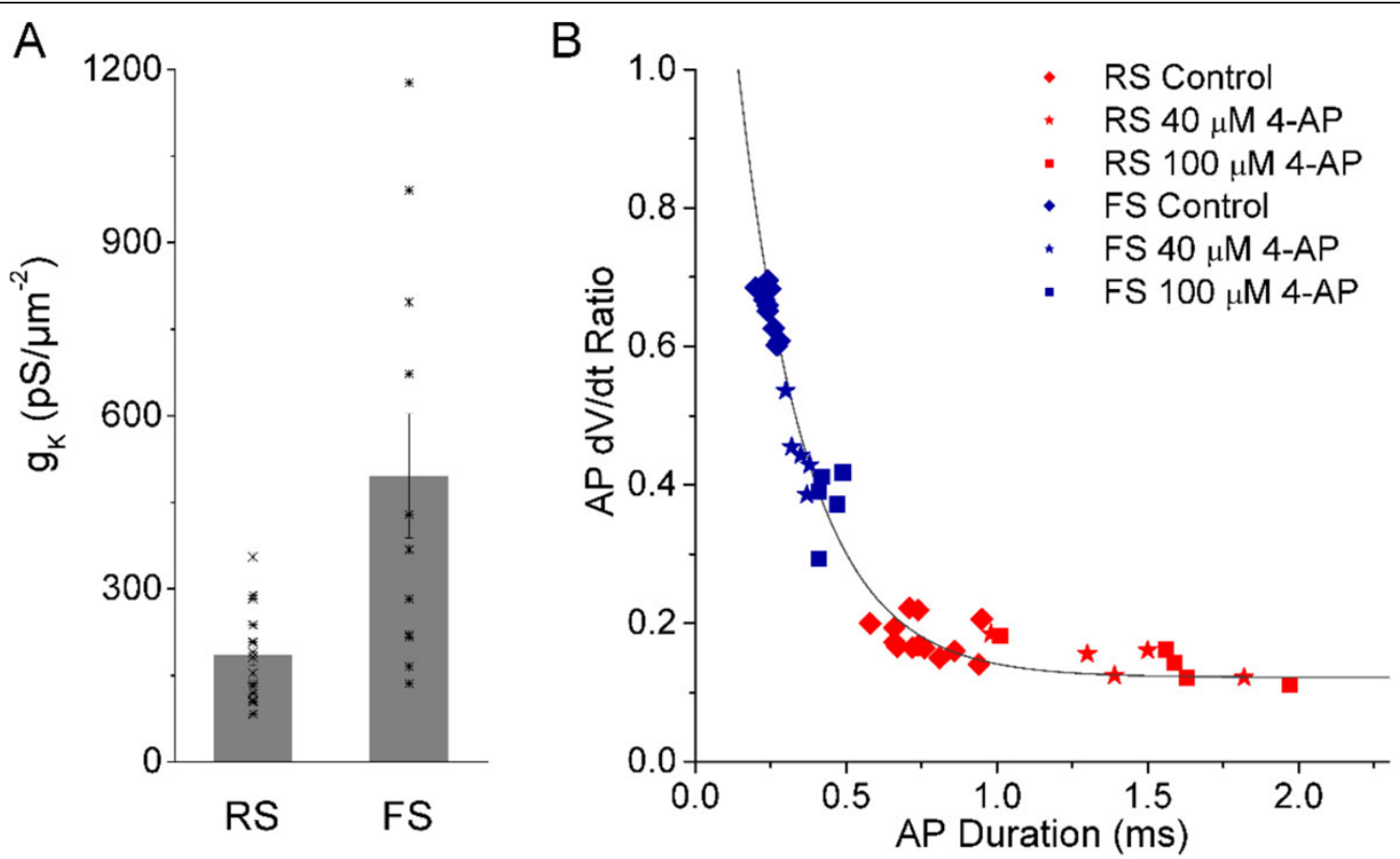

Figure $1 \mathrm{~A}$. The bar graph shows peak $\mathrm{K}+$ conductance density recorded in axon initial segment of cells (16 recording axons for RS pyramidal cell, 11 for FS interneuron) by outside-out axon patch recording technique. B. Summary of the results from partially blocking $\mathrm{K}$ + channels. The AP dV/dt ratio is an exponentially decaying function of the spike duration.

\footnotetext{
* Correspondence: yuyuguo@fudan.edu.cn

The State Key Laboratory of Medical Neurobiology and Institutes of Brain Science, School of Life Sciences, Fudan University, Shanghai, 200433;China
} 
RS pyramidal cells and FS PV cells, partially blocking K+ channels by applying 4-AP broadened the spike duration and decreased the $\mathrm{dV} / \mathrm{dt}$ ratio significantly $(\mathrm{P}<0.05)$ (For RS cells: $N=5$; For RS cells: $N=4$ ). Interestingly, we observed that the AP $\mathrm{dV} / \mathrm{dt}$ ratio is an exponentially decaying function of the spike duration for both RS- and FS-spikings (see Figure 1B), such that $y=0.12+0.16 \mathrm{EXP}$ $((0.5-\mathrm{x}) / 0.2)$, where $y$ represents the $\mathrm{dV} / \mathrm{dt}$ ratio and $x$ represents the AP duration. These observations suggest strongly that potassium channel density is one of the major intrinsic factors dominating the spike shape properties, especially half-height spike duration and $\mathrm{dV} / \mathrm{dt}$ ratio.

In sum, the significant difference in potassium channel density in axonal initial segment where action potentials are initiated may play a critical role in controlling action potential properties of both RS- and FS-spiking cells in nervous system by the same general biophysical rule. These results may be important for constructing computational models of different types of cortical neurons.

\section{Acknowledgements}

This project is funded by NNSF of China (31271170) and Eastern Scholar

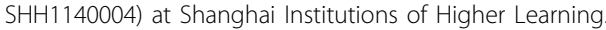

Published: 18 December 2015

\section{References}

1. Hu W, Tian C, Li T, Yang M, Hou H, Shu Y: Distinct contributions of $\mathrm{Na}(\mathrm{v})$ 1.6 and $\mathrm{Na}(\mathrm{v}) 1.2$ in action potential initiation and backpropagation. Nat Neurosci 2009, 12(8):996-1002.

2. Hu $\mathrm{H}$, Jonas $\mathrm{P}:$ A supercritical density of $\mathrm{Na}(+)$ channels ensures fast signaling in GABAergic interneuron axons. Nat Neurosci 2014, 17(5):686-693.

3. Li T, Tian C, Scalmani P, Frassoni C, Mantegazza M, Wang Y, Yang M, Wu S, Shu Y: Action potential initiation in neocortical inhibitory interneurons. PLOS Biol 2014, 12(9):e1001944.

doi:10.1186/1471-2202-16-S1-P295

Cite this article as: Zhang et al:: Axon initial segment potassium channel density in cortical neurons. BMC Neuroscience 2015 16(Suppl 1): P295.

\section{Submit your next manuscript to BioMed Central} and take full advantage of:

- Convenient online submission

- Thorough peer review

- No space constraints or color figure charges

- Immediate publication on acceptance

- Inclusion in PubMed, CAS, Scopus and Google Scholar

- Research which is freely available for redistribution

Submit your manuscript at www.biomedcentral.com/submit
C Biomed Central 